\title{
Metabolic Profile of Japanese Black Breeding Cattle Herds: Usefulness in Selection for Nutrient Supplementation to Enhance Reproductive Performance and Regional Differences
}

\author{
Urara WATANABE ${ }^{1,2}$, Mitsuhiro TAKAGI ${ }^{1,3) *}$, Osamu YAMATO ${ }^{1,3)}$, Takeshige OTOI ${ }^{1,4)}$, Chenga TSHERING ${ }^{5)}$ and \\ Koji OKAMOTO2)
}

1) United Graduate School of Veterinary Sciences, Yamaguchi University, Yamaguchi 753-8515, Japan

${ }^{2)}$ Soo Agriculture Mutual Aid Association, Kagoshima 899-8212, Japan

3) Joint Faculty of Veterinary Medicine, Kagoshima University, Kagoshima 890-0064, Japan

4) Joint Faculty of Veterinary Medicine, Yamaguchi University, Yamaguchi 753-8515, Japan

${ }^{5)}$ Regional Livestock Development Center, Zhemgang, Bhutan

(Received 2 October 2012/Accepted 16 November 2012/Published online in J-STAGE 30 November 2012)

ABSTRACT. The study aims were (1) to confirm the effects of nutritional improvement in prepartal and postpartal periods, monitored using the serum metabolic profile test (MPT) and reproductive performance, and (2) to clarify regional characteristics of the MPT results within our jurisdiction by using our MPT database. Experiment 1: Among 42 breeding cattle herds in our jurisdiction mainly fed home-pasture roughage, 3 experimental herds showing subnormal blood urea nitrogen (BUN) levels were selected and compared with 1 representative excellent herd. Dietary remedial measures were implemented from feed analysis in each herd. BUN concentration in all 3 herds increased significantly, and open days postpartum in 2 of the herds were significantly reduced, compared with values before dietary supplementation. Experiment 2: Thirty-seven herds within our jurisdiction were grouped into 3 categories (Area 1,2 and 3) by location and soil condition of the herd pastureland. The MPT and reproductive performance in cows whose blood samples were collected at both prepartum (60-20 days before calving) and postpartum (30-90 days after calving) were compared among the 3 areas. Significant regional differences were found in prepartal albumin, total cholesterol, BUN, and glucose and postpartal BUN, glucose and open days $(P<0.05)$. Overall, the MPT (especially BUN) might be useful for determining the metabolic nutritional status of breeding cattle herds, particularly those fed home-pasture roughage. Additionally, poor/unsatisfactory reproductive performance of beef breeding cattle herds probably reflects inadequate nutritional content of the diet, possibly arising from regional pastureland differences.

KEY WORDS: blood urea nitrogen, Japanese Black cow, metabolic profile, nutrient supplementation, reproductive performance.

doi: 10.1292/jvms.12-0441; J. Vet. Med. Sci. 75(4): 481-487, 2013

For optimal beef breeder production, a calving interval of 1 year must be maintained. Thus, the first postpartum estrus must occur within 80 to 85 days after parturition, and this is closely associated with the postpartum interval to first ovulation [19]. Several factors, such as the extent of calf suckling, reproductive failure, genetic variation and level of maternal nutrient intake, affect postpartum reproductive performance of beef cows [15, 16, 18]. Among them, one of the major factors contributing to a prolonged calving to conception interval is inadequate nutrition, which often causes subclinical and/or clinical metabolic diseases [3, 10]. Prepartal and postpartal nutritional statuses are also related to the interval between calving and first ovulation in beef cattle [10]. Thus, it was assumed that certain metabolic parameters, which might reflect the energy and protein status of cows during prepartum and postpartum, would be associated with reproductive performance of breeding cattle herds.

Payne et al. [11] first established the metabolic profile as

*Correspondence to: Takagi, M., Joint Faculty of Veterinary Medicine, Kagoshima University, Kagoshima 890-0065, Japan. e-mail: mtakagi@agri.kagoshima-u.ac.jp

(C)2013 The Japanese Society of Veterinary Science a tool for assessing metabolic status and aiding the diagnosis of metabolic disorders in dairy herds, and currently the metabolic profile is considered an extremely useful tool for objective nutritional evaluation in dairy herds in Japan [5]. Though some researchers have indicated that the results of the metabolic profile test (MPT) such as total cholesterol (T-Cho) and blood urea nitrogen (BUN) determined from serum biochemical analysis may be used to improve feeding management, detect subclinical health problems, and prevent production problems of the Japanese Black breeding herds [9, 22], its practical application has mainly focused on the management of dairy cattle. This may be due to the lack of reference values for each metabolite based on blood biochemical data derived from a reliable number of samples and/or the wide variations in feeding management among herds in the same region/locality, which could ultimately affect the results of the MPT. On the other hand, in rural areas of Japan, such as in the study area included in the current study (the Osumi Peninsula, Kagoshima Prefecture, Japan), most of the breeding beef cattle herds are fed hays collected from their home pastureland. Recently, the importance of this beef-forage production system of Japanese Black cattle has been re-recognized, because it contributes to improved nutrient utilization (ecological aspect) and reduced cost of 
commercial feeds (economical aspect) [17, 20]. However, no evaluative study has been conducted to investigate the nutritional adequacy of forage collected from the home pastureland. Therefore, it was hypothesized that the MPT might be useful for detecting nutritional inadequacies reflected as subclinical metabolic and reproductive disorders in the respective herds.

Recently, during our routine assessments of metabolic profiles of farms in our jurisdiction, we detected one herd in which all reared cows exhibited abnormal BUN levels (mean, $2.2 \mathrm{mg} / \mathrm{d} l$; range, $1.6-4.0 \mathrm{mg} / \mathrm{d} l$ ) without any clinical symptoms. It was hypothesized that this observation might be due to crude protein (CP) deficiency in the roughage [21]. Therefore, regional differences of the MPT due to nutritional quality of fed roughage harvested from the home pastureland were assumed to exist.

In the present study, to confirm the result of our previous report [21] with the inclusion of additional herds, the effect of nutritional improvement on the prepartal and postpartal MPTs and reproductive performance in each herd was evaluated. Furthermore, we used our database to evaluate the metabolic profile of the herds according to their location in our jurisdiction-Kanoya, Soo and Shibushi Cities; Kagoshima Prefecture; Japan.

\section{MATERIALS AND METHODS}

Experiment 1-Evaluation of the usefulness of metabolic profiles for breeding herd management: Animals and herds. Private Japanese Black breeding herds under the jurisdiction of Soo Veterinary Clinical Center, Soo Agriculture Mutual Aid Association, Kagoshima Prefecture, Japan, were identified for this study. From our database, the metabolic profiles of 42 Japanese Black breeding cattle herds collected from June 2010 through May 2012 were evaluated. The cows of all herds were mainly fed roughage harvested from the home pasture of each herd and available commercial concentrates supplemented with certain vitamins and minerals. We previously reported the usefulness of metabolic profiles in 1 herd in which all reared cows exhibited abnormally low BUN levels [21]. Therefore, in the present investigation, to validate the results of our MPT system, we selected 3 herds (experimental herds) in which the metabolic profile, particularly BUN concentration and reproductive performance, such as number of open days postpartum and frequency of treatments for reproductive disorders, were suggestive of subclinical metabolic disorder during the sampling period. Additionally, 1 herd was selected as a representative model of herd excellence on the basis of the same selection parameters for comparison with the experimental herds. These herds were located in the same area (Soo City, Kagoshima Prefecture) and selected on the basis of standard normal reference ranges for the serum biochemical parameters [13].

Blood sampling and serum biochemical analysis of metabolic parameters. In all cases, blood sampling and serum biochemical analysis were conducted according to our previous study protocol [21], which depended on herd size. All cows were sampled in herds in which less than 20 cows were fed, while approximately 10 cows were samples from each of the prepartal and postpartal periods in herds in which more than 20 cows were fed. Briefly, blood samples were collected from the jugular vein of selected cows of each herd after morning feeding, and serum was separated within $2 \mathrm{hr}$ after collection and stored in a refrigerator until processing. Biochemical analysis was performed to determine the following parameters: glucose (Glu), free fatty acids (FFA) and T-Cho for evaluation of energy metabolism and total protein (TP), serum albumin (Alb), albumin/globulin ratio $(\mathrm{A} / \mathrm{G})$ and $\mathrm{BUN}$ for protein metabolism (measured on a Labospect 7080 autoanalyzer; Hitachi, Tokyo, Japan). In the present study, only the cows whose blood samples were collected at both prepartum (between 60 and 20 days before parturition) and postpartum (between 30 and 90 days after parturition) were selected for data analysis of Herds 2, 3 and 4 , because the nutritional condition of breeding cattle during both prepartum and postpartum may have marked effects on the duration of the postpartum interval from calving to first estrus [10].

To assess energy balance, the mean body condition score (BCS) of the herd on a scale of 1 (too thin) to 5 (obese) was also determined by 2 skilled veterinarians [5].

Nutritional evaluation. At the time of blood sampling, roughage samples foraged by each herd as well as any fed concentrates were collected for nutritional evaluation of the selected herds. The nutrient compositions of the roughage were measured according to our previous report by nearinfrared reflecting spectroscopy (NIRS6500; Nireco Corporation, Tokyo, Japan) [21], which was verified according to the Japanese Feeding Standard [1], and nutrient ingredients in the roughage were calculated as dry matter (DM), total digestible nutrients (TDN) and CP.

Dietary recommendations for the herds based on the biochemical and nutritional analyses and repeat blood tests. On the basis of the biochemical analyses and nutritional evaluation of the dietary feeds of the 4 herds, dietary remedial measures aimed at improving both energy and protein intakes were implemented according to our previous report [21]. Briefly, the herd owners were advised to modify the feed composition by supplementing the diet with bean cake (0.6 kg).

Several months after this dietary remedial measure was introduced, the serum biochemical parameters and reproductive performance of the herds were reexamined as described above. Again, only the blood samples collected during the prepartal and postpartal stages were selected for the evaluation of serum biochemical parameters. Additionally, reproductive performance, such as the frequency of clinical treatments for reproductive disorders and open days, of the selected herds before and after the introduction of the remedial measure was evaluated.

Experiment 2-Evaluation of the metabolic profile of breeding herds according to location in our practice jurisdiction: Japanese Black breeding herds and cows. A total of 37 private Japanese Black breeding herds under the jurisdiction of Soo Veterinary Clinical Center, Soo Agriculture Mutual Aid Association, Kagoshima Prefecture, Japan, were 
identified for this study. Cows included in this study were of different ages and in different states of the reproductive cycle without any visible signs of clinical disease. All cows were housed indoors and fed roughage collected from the home pastureland and supplementary concentrate purchased from various feed companies; however, feeding and management varied among herds. The herds were grouped into 3 categories (Area 1, Kanoya City; Area 2, Soo City; and Area 3, Shibushi City) according to the soil characteristics and the geographic location of the property within our jurisdiction (Fig. 1). Briefly, the pasturelands for cattle herds in Area 1 were cultivated lands for growing crops on which roughages were grown after harvesting, while the pasturelands of herds in Areas 2 and 3 were used only for growing roughages; thus, the pasturelands in Area 1 were considered well-managed fertilized soil (with the use of both compost and slack or dolomitic lime) compared with pasturelands of Areas 2 and 3 (with the use of compost only).

Blood collection, metabolic profile parameters, and data analytical methods. According to the request of the herd owners, blood collections were scheduled to incorporate all seasons from October 2010 through December 2011. Blood samples were collected from the jugular vein in plain vacuum tubes as described above. Serum was separated from the blood within $2 \mathrm{hr}$ after collection and stored in a refrigerator until processing. The following biochemical parameters were determined: Glu, FFA and T-Cho for evaluation of energy metabolism; TP, Alb, AG and BUN for protein metabolism; and serum aspartate aminotransferase (AST) and $\gamma$-glutamyltransferase (GGT) for liver function (measured on a Labospect 7080 autoanalyzer; Hitachi). For the same reason as described above, cows whose blood samples were collected at both prepartum (between 60 and 20 days before calving) and postpartum (between 30 and 90 days after calving) were selected for evaluation of the metabolic status of each herd by using the results of serum biochemical analysis.

Additionally, reproductive performance data were obtained from each herd record at the same time as blood sampling; data included postpartum open days during the postpartal period to the time of pregnancy confirmation in individual cows. BCS of each cow was also determined to assess energy balance at the time of blood sampling of the herd.

Statistical analysis. The results of serum biochemical analysis, open days postpartum, and frequency of clinical treatments before and after implementation of the dietary remedial measure were compared using the Student's $t$ test and Chi-square test. The results obtained for each herd are expressed as the mean $\pm \mathrm{SD}$. The results of serum biochemical analysis collected both in the prepartal and in the postpartal periods were compared among sampling areas by ANOVA using the General Linear Model function of SAS. $P$ values less than 0.05 were considered to indicate a statistically significant difference, while $P$ values less than 0.1 were considered to indicate a significant tendency.

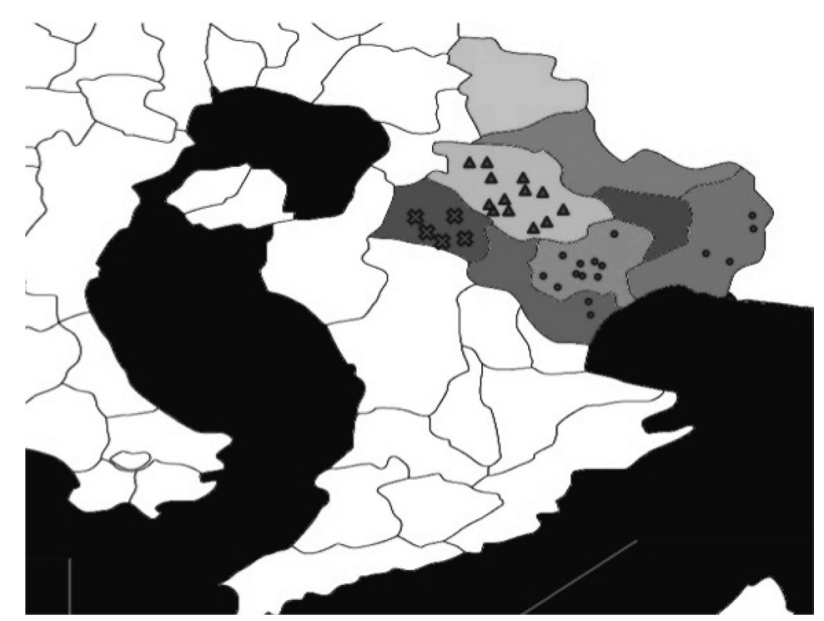

Fig. 1. The 3 regions of the sampled herds in Osumi Peninsula, Kagoshima Prefecture, Japan. ×: Area 1, $\mathbf{\Delta}$ : Area 2, •: Area 3.

\section{RESULTS}

Experiment 1-Body condition score, serum biochemical analysis and reproductive performance before and after dietary supplementation in each herd: Four herds from the same area were selected for this evaluation, including 1 herd with excellent reproductive performance (Herd 1: No. of breeding cows, $\mathrm{n}=55$ ) and 3 herds as experimental herds (Herd 2, n=21; Herd 3, n=115; and Herd 4, n=20), according to baseline metabolic profiles. The compositions of feeds provided to the 4 herds both before and after dietary supplementation are shown in Table 1, and the results of serum biochemical analysis and reproductive performance in each herd before and after dietary supplementation are shown in Table 2 .

The results of biochemical analyses of Herd 1, the representative excellent herd, were all within the normal ranges, with a BUN value of $18.7 \mathrm{mg} / \mathrm{d} l$. The open days postpartum was 47.2 , and the number of treatments for reproductive disorders during the postpartum period was only 1 in the herd of 6 cows. The mean BCS of Herd 1 was 3.0-3.5; further, the mean BCS at the second blood sampling was statistically comparable to that at the first blood sampling in the 3 experimental herds (approximately 3.0-3.5 for both).

In Herd 2, BUN concentration was significantly increased after dietary supplementation (before, $8.6 \mathrm{mg} / \mathrm{d} l$; after, 12.5 $\mathrm{mg} / \mathrm{d} l$ ), but no significant differences were observed in the other serum biochemical parameters. The reproductive performance of Herd 2 was significantly improved; the number of open days postpartum following the dietary remedial measure (57.9 days) was significantly decreased compared with that observed before the introduction of the dietary remedial measure (73.5 days). Additionally, the frequency of treatments for reproductive failures following the dietary remedial measure ( 3 times per 14 postpartum cows) tended to decrease significantly $(P=0.053)$ compared with that before the introduction of the dietary remedial measure $(8$ times per 14 cows). 
Table 1. Composition of feed provided to the Japanese Black cattle herds kept for breeding purposes

\begin{tabular}{|c|c|c|c|c|c|c|c|c|c|c|}
\hline \multirow[b]{2}{*}{ Herd } & & \multirow{2}{*}{$\begin{array}{c}\text { Forage feed } \\
\mathrm{kg}\end{array}$} & \multicolumn{5}{|c|}{ Concentrate feed } & \multicolumn{3}{|c|}{ Fullness rate } \\
\hline & & & $\begin{array}{c}\text { Total } \\
\mathrm{kg}\end{array}$ & $\begin{array}{c}\text { Bran } \\
\%\end{array}$ & $\begin{array}{c}\text { Cereal } \\
\%\end{array}$ & $\begin{array}{l}\text { Oil seed } \\
\text { meal, \% }\end{array}$ & $\begin{array}{c}\text { Other } \\
\%\end{array}$ & $\begin{array}{c}\mathrm{DM} \\
\%\end{array}$ & $\begin{array}{c}\text { TDN } \\
\%\end{array}$ & $\begin{array}{l}\mathrm{CP} \\
\%\end{array}$ \\
\hline 1 & Before* & Italian ryegrass + oats hay 8 & 2 & 15 & 24 & 5 & 56 & 101 & 120 & 151 \\
\hline \multirow[b]{2}{*}{2} & Before & Italian ryegrass 6 & 2 & 33 & 47 & 15 & 5 & 96 & 78 & 60 \\
\hline & After** & Italian ryegrass 6 & 2 & 33 & 47 & 15 & 5 & 100 & 99 & 105 \\
\hline \multirow[b]{2}{*}{3} & Before & Italian ryegrass 8.9 & 0.5 & 41 & 43 & 12 & 4 & 99 & 96 & 106 \\
\hline & After & Italian ryegrass 8.9 & 0.5 & 41 & 43 & 12 & 4 & 110 & 110 & 145 \\
\hline \multirow[t]{2}{*}{4} & Before & $\begin{array}{l}\text { Barnyard grass silage } 8+\text { Bermuda straw } 2.5 \\
+ \text { sorghum } 2.4\end{array}$ & 2 & 15 & 24 & 5 & 56 & 112 & 122 & 130 \\
\hline & After & Same as before & 2 & 15 & 24 & 5 & 56 & 117 & 132 & 153 \\
\hline
\end{tabular}

*: before the dietary remedial measure, $* *$ : after the dietary remedial measure.DM: dry matter, TDN: total digestible nutrients, CP: crude protein. \#: fullness rate in the case of $100 \%$ dry matter intake.

Table 2. Summaries of serum biochemical analyses and reproductive records (mean \pm SD) of selected Japanese Black herds in the same area before and after dietary supplementation

\begin{tabular}{|c|c|c|c|c|c|c|c|}
\hline & Herd 1 & \multicolumn{2}{|c|}{ Herd 2} & \multicolumn{2}{|c|}{ Herd 3} & \multicolumn{2}{|c|}{ Herd 4} \\
\hline $\begin{array}{l}\text { Main diagnoses of feed } \\
\text { analysis }\end{array}$ & ND & $\begin{array}{r}\text { TDN and CP } \\
\text { den }\end{array}$ & $\begin{array}{l}\text { ufficient for } \\
\text { dd }\end{array}$ & $\begin{array}{r}\text { TDN and CP i } \\
\text { dem }\end{array}$ & $\begin{array}{l}\text { isufficient for } \\
\text { and }\end{array}$ & $\mathrm{CP}$ insufficier & for demand \\
\hline \multirow[t]{2}{*}{ Follow-up period } & & \multicolumn{2}{|c|}{2 months } & \multicolumn{2}{|c|}{6 months } & \multicolumn{2}{|c|}{6 months } \\
\hline & Before* & Before & After** & Before & After & Before & After \\
\hline No. of cows & 5 & 6 & 4 & 5 & 4 & 13 & 14 \\
\hline $\mathrm{TP}(\mathrm{g} / \mathrm{d} l)$ & $7.0 \pm 0.3$ & $7.9 \pm 0.9$ & $7.7 \pm 0.6$ & $7.4 \pm 0.5$ & $7.3 \pm 0.7$ & $7.7 \pm 0.3^{\mathrm{a})}$ & $7.3 \pm 0.4^{b)}$ \\
\hline $\mathrm{Alb}(\mathrm{mg} / \mathrm{d} l)$ & $3.5 \pm 0.4$ & $3.5 \pm 0.2$ & $3.7 \pm 0.3$ & $3.3 \pm 0.1^{\mathrm{a})}$ & $3.5 \pm 0.1^{\mathrm{b})}$ & $3.6 \pm 0.2^{\mathrm{a})}$ & $3.4 \pm 0.2^{\mathrm{b})}$ \\
\hline $\mathrm{A} / \mathrm{G}$ & $1.0 \pm 0.1$ & $0.8 \pm 0.1$ & $0.9 \pm 0.1$ & $0.8 \pm 0.2$ & $1.0 \pm 0.2$ & $0.9 \pm 0.1$ & $0.9 \pm 0.2$ \\
\hline $\mathrm{FFA}(\mathrm{mmol} / \mathrm{l})$ & $98.8 \pm 30.9$ & $142.7 \pm 93.3$ & $68.8 \pm 13.0$ & $232.4 \pm 132.8^{a)}$ & $64.3 \pm 51.0^{\mathrm{b})}$ & $73.1 \pm 32.3^{\mathrm{a})}$ & $\left.114.4 \pm 57.9^{b}\right)$ \\
\hline T-Cho $(\mathrm{mg} / \mathrm{d} l)$ & $123.2 \pm 14.8$ & $114.9 \pm 30.2$ & $91.9 \pm 5.1$ & $100.8 \pm 20.5^{\mathrm{a})}$ & $145.1 \pm 17.3^{\mathrm{b})}$ & $138.2 \pm 33.8^{a)}$ & $111.1 \pm 16.2^{\mathrm{b})}$ \\
\hline $\mathrm{BUN}(\mathrm{mg} / \mathrm{d} l)$ & $18.7 \pm 1.6$ & $8.6 \pm 2.3^{\mathrm{a})}$ & $12.5 \pm 1.6^{\mathrm{b})}$ & $10.6 \pm 2.1^{\mathrm{a})}$ & $13.6 \pm 1.2^{\mathrm{b})}$ & $6.5 \pm 1.0^{\mathrm{a})}$ & $9.8 \pm 1.3^{\mathrm{b})}$ \\
\hline Glu $(\mathrm{mg} / \mathrm{d} l)$ & $52.3 \pm 3.0$ & $45.0 \pm 2.4$ & $44.5 \pm 4.6$ & $49.3 \pm 4.2^{\mathrm{a})}$ & $61.3 \pm 3.0^{\mathrm{b})}$ & $57.7 \pm 4.1$ & $56.8 \pm 3.5$ \\
\hline Days open (days) & 47.2 & $73.5 \pm 16.0^{\mathrm{a})}$ & $57.9 \pm 15.9^{\text {b) }}$ & $76.2 \pm 15.4$ & $64.0 \pm 9.6$ & $122.5 \pm 56.6^{\mathrm{a})}$ & $77.3 \pm 48.4^{b)}$ \\
\hline $\begin{array}{l}\text { Reproductive disorder }{ }^{\#} \\
\text { (time/head) }\end{array}$ & $1 / 6$ & $8 / 14^{\mathrm{c})}$ & $3 / 14^{\mathrm{d})}$ & $5 / 9^{c)}$ & $1 / 8^{\mathrm{d})}$ & $4 / 13$ & $2 / 13$ \\
\hline
\end{tabular}

Herd 1: representative of an excellent cattle herd; Herds 2,3 and 4: experimental herds selected according to the results of serum biochemical analysis $*$ : before the dietary remedial measure, $* *$ : after the dietary remedial measure, ND: not determined. a, b) significantly different within the same herd $(P<0.05), \mathrm{c}, \mathrm{d})$ significantly different within the same herd $(P<0.1)$. \#: frequency of treatments for reproductive disorders during the period from calving to conception.

In Herd 3, regarding the parameters for protein metabolism, significant increases were observed in Alb (before, 3.3 $\mathrm{mg} / \mathrm{d} l$; after, $3.5 \mathrm{mg} / \mathrm{d} l$ ) and BUN (before, $10.6 \mathrm{mg} / \mathrm{d} l$; after, $13.6 \mathrm{mg} / \mathrm{d} l$ ) and regarding the parameters for energy metabolism, significant increases were observed in T-Cho (before, $100.8 \mathrm{mg} / \mathrm{d} l$; after, $145.1 \mathrm{mg} / \mathrm{d} l$ ) and Glu (before, $49.3 \mathrm{mg} / \mathrm{d} l$; after, $61.3 \mathrm{mg} / \mathrm{d} l$ ), and a significant decrease was observed in FFA (before, $232.4 \mu \mathrm{Eq} / l$; after, $64.3 \mu \mathrm{Eq} / l$ ). Although no significant differences were found, the reproductive performance of Herd 3 was improved; the open days postpartum following the dietary remedial measure (64.0 days) was decreased compared with that observed before the introduction of the dietary remedial measure (76.2 days). Additionally, the frequency of treatments for reproductive failures following the dietary remedial measure ( 1 time per 8 postpartum cows) tended to decrease significantly $(P=0.06)$ compared with that before the introduction of the dietary remedial measure ( 5 times per 9 cows).

In Herd 4, regarding the parameters for protein metabolism, significant decreases were observed in TP (before, 7.7 $\mathrm{mg} / \mathrm{d} l$; after, $7.3 \mathrm{mg} / \mathrm{d} l$ ) and $\mathrm{Alb}$ (before, $3.6 \mathrm{mg} / \mathrm{d} l$; after, $3.4 \mathrm{mg} / \mathrm{d} l$ ), and a significant increase was observed in BUN (before, $6.5 \mathrm{mg} / \mathrm{d} l$; after, $9.8 \mathrm{mg} / \mathrm{d} l$ ) after remedy supplementation. Regarding the parameters for energy metabolism, a significant increase was observed in FFA (before, 73.1 $\mu \mathrm{Eq} / l$; after, $114.4 \mu \mathrm{Eq} / l$ ), but T-Cho (before, $138.2 \mathrm{mg} / \mathrm{d} l$; after, $111.1 \mathrm{mg} / \mathrm{d} l$ ) was significantly decreased after supplementation. The reproductive performance of Herd 4 was significantly improved; the open days postpartum following the dietary remedial measure (77.3 days) was significantly decreased compared with that observed before the introduction of the dietary remedial measure (122.5 days). Additionally, the frequency of treatments for reproductive failures following the dietary remedial measure ( 2 times per 13 postpartum 
Table 3. Serum biochemical analyses (mean $\pm \mathrm{SD})$ and postpartum open days of the herds derived from different regions of our jurisdiction in the Osumi Peninsula whose blood samples were collected during the prepartum

\begin{tabular}{|c|c|c|c|}
\hline & Area 1 & Area 2 & Area 3 \\
\hline No. of herd & 9 & 4 & 19 \\
\hline No. of cows & 30 & 16 & 64 \\
\hline $\mathrm{TP}(\mathrm{g} / \mathrm{d} l)$ & $7.3 \pm 0.5$ & $7.1 \pm 0.5$ & $7.3 \pm 0.3$ \\
\hline $\mathrm{Alb}(\mathrm{mg} / \mathrm{d} l)$ & $3.4 \pm 0.2^{\mathrm{a})}$ & $3.2 \pm 0.4^{b)}$ & $3.3 \pm 0.3$ \\
\hline $\mathrm{A} / \mathrm{G}$ & $0.9 \pm 0.1$ & $0.8 \pm 0.2$ & $0.8 \pm 0.2$ \\
\hline GOT (U/l) & $53.2 \pm 11.4$ & $53.7 \pm 11.5$ & $53.5 \pm 10.0$ \\
\hline GGT (U/l) & $15.9 \pm 3.5$ & $17.1 \pm 3.1$ & $16.9 \pm 3.8$ \\
\hline $\mathrm{FFA}(\mathrm{mmol} / \mathrm{l})$ & $208.7 \pm 254.9$ & $206.9 \pm 153.9$ & $206.2 \pm 164.2$ \\
\hline T-Cho $(\mathrm{mg} / \mathrm{d} l)$ & $113.1 \pm 21.9$ & $103.8 \pm 20.1^{a)}$ & $121.4 \pm 27.5^{b)}$ \\
\hline BUN $(\mathrm{mg} / \mathrm{d} l)$ & $11.3 \pm 3.1^{\mathrm{a})}$ & $8.4 \pm 4.4^{b)}$ & $9.6 \pm 3.5^{b)}$ \\
\hline $\mathrm{Glu}(\mathrm{mg} / \mathrm{d} l)$ & $54.2 \pm 6.5^{\mathrm{a})}$ & $47.6 \pm 8.0^{b)}$ & $49.5 \pm 8.0^{\mathrm{b})}$ \\
\hline Day open (days) & $70.6(n=20)$ & $78.8(\mathrm{n}=15)$ & $98.0(\mathrm{n}=41)$ \\
\hline
\end{tabular}

Prepartum: blood sampling was conducted between 60 and 20 days before calving. $\mathrm{a}, \mathrm{b})$ significant difference within the same row $(P<0.05)$.

cows) was reduced without significance compared with that before the introduction of the dietary remedial measure (4 times per 13 cows).

Experiment 2-Serum biochemical analysis and open days postpartum of cattle herds derived from 3 different regions: Data from the cows whose samples were collected at prepartum. The results of serum biochemical analyses derived from cattle herds in the 3 regions whose samples were collected at prepartum are shown in Table 3. Significant differences were observed in Alb (Area 1, $3.4 \mathrm{~g} / \mathrm{d} l$; Area 2, 3.2 $\mathrm{g} / \mathrm{d} l$ ), T-Chol (Area 2, $103.8 \mathrm{mg} / \mathrm{d} l$; Area 3, $121.4 \mathrm{mg} / \mathrm{d} l$ ), BUN (Area 1, $11.3 \mathrm{mg} / \mathrm{d} l$; Area 2, $8.4 \mathrm{mg} / \mathrm{dl}$; and Area 3, 9.6 $\mathrm{mg} / \mathrm{d} l$ ) and Glu (Area $1,54.2 \mathrm{mg} / \mathrm{d} l$; Area 2, $47.6 \mathrm{mg} / \mathrm{d} l$; and Area $3,49.5 \mathrm{mg} / \mathrm{d} l$ ). The mean open days postpartum did not differ significantly among the 3 regions.

Data from the cows whose samples were collected at postpartum. The results of serum biochemical analyses derived from cattle herds in the 3 regions whose samples were collected at postpartum are in Table 4. Significant differences were observed in BUN (Area 1, $10.4 \mathrm{mg} / \mathrm{d} l$; and Area 2, 8.3 $\mathrm{mg} / \mathrm{d} l$ ) and Glu (Area $1,59.0 \mathrm{mg} / \mathrm{d} l$; and Area $2,52.8 \mathrm{mg} / \mathrm{d} l$ ). A significant difference was observed in the open days postpartum between Area 1 (75.9 days) and Area 2 (113.4 days).

\section{DISCUSSION}

Results of the present study suggest that (1) nutritional supplementation (mainly bean cake in the present study) based on the results of the MPT might help to improve the reproductive performance of breeding herds with energy/CP deficiency compared with excellently managed herds in our jurisdiction and (2) nutritional metabolic profile parameters differ according to area in breeding cows in our jurisdiction.

In the present study, we investigated the usefulness of the MPT to enhance reproductive performance. It has been reported that prepartal and postpartal nutritional levels are the
Table 4. Serum biochemical analyses $(m e a n \pm S D)$ and postpartum open days of the herds derived from different regions of our jurisdiction in the Osumi Peninsula whose blood samples were collected during the postpartum

\begin{tabular}{lccc}
\hline & Area 1 & Area 2 & Area 3 \\
\hline No. of herd & 10 & 7 & 19 \\
\hline No. of cows & 36 & 39 & 75 \\
\hline TP $(\mathrm{g} / \mathrm{d} l)$ & $7.7 \pm 0.7$ & $7.5 \pm 0.5$ & $7.5 \pm 0.5$ \\
Alb $(\mathrm{mg} / \mathrm{d} l)$ & $3.5 \pm 0.3$ & $3.4 \pm 0.4$ & $3.4 \pm 0.3$ \\
A/G & $0.8 \pm 0.1$ & $0.9 \pm 0.2$ & $0.8 \pm 0.2$ \\
GOT $(\mathrm{U} / l)$ & $63.6 \pm 22.9$ & $60.6 \pm 9.7$ & $61.8 \pm 13.9$ \\
GGT $(\mathrm{U} / l)$ & $18.7 \pm 4.0$ & $20.2 \pm 6.3$ & $19.9 \pm 8.4$ \\
FFA $(\mathrm{mmol} / l)$ & $102.7 \pm 121.1$ & $139.7 \pm 95.7$ & $128.3 \pm 103.4$ \\
T-Cho $(\mathrm{mg} / \mathrm{d} l)$ & $123.7 \pm 41.0$ & $120.2 \pm 35.4$ & $123.2 \pm 29.3$ \\
BUN $(\mathrm{mg} / \mathrm{d} l)$ & $10.4 \pm 3.6^{\text {a) }}$ & $8.3 \pm 4.1^{\mathrm{b})}$ & $8.9 \pm 3.1$ \\
Glu $(\mathrm{mg} / \mathrm{d} l)$ & $59.0 \pm 9.5^{\text {a) }}$ & $52.8 \pm 10.1^{\mathrm{b})}$ & $56.5 \pm 6.6$ \\
\hline Days open $($ days $)$ & $75.9^{\text {a) }}(\mathrm{n}=27)$ & $113.4^{\text {b) }}(\mathrm{n}=27)$ & $82.6(\mathrm{n}=43)$ \\
\hline Pospattm
\end{tabular}

Postpartum: blood sampling was conducted between 30 and 90 days after calving. a, b) significant difference within the same row $(P<0.05)$.

most important factors for decreasing the interval between parturition and first ovulation $[3,16]$, and weight gain and body condition during these periods are extremely important to decrease postpartum anestrus in beef cattle $[3,8]$. The results of the present study comprising 3 herds (Herds 2, 3 and 4), in which we evaluated the MPT results before and after dietary supplementation, clearly indicated the shortening of the postpartal open-day period in each herd, concomitant with not only increased BUN concentration but also decreased FFA concentration, except for Herd 4, which probably reflected an upturn of adequate protein intake and positive energy balance of the cows. Additionally, improved reproductive performance with decreased treatments for reproductive failure was observed in the present study, even though calving intervals were less than 1 year before the dietary remedy was implemented in all the experimental herds. Although hormonal treatments for reproductive failure of cattle are important tools to control breeding or remedy reproductive failure and proper use of hormones does not have any known negative effect on animal welfare or public health to date, it must be emphasized that animal health and fertility should be improved by good management rather than by extensive use of hormones [14]. Therefore, on the basis of the results from the albeit limited number of herds together with our previous report [21], we concluded that metabolic profile examination for detecting subclinical metabolic failure of breeding herds together with appropriate nutritional supplementation is an effective and essential tool for on-farm breeding cattle herds.

Although reports exist regarding the application of examination of metabolic profiles for Japanese Black breeding cattle $[9,22]$, most of the studies were conducted in intensive herds or under experimental controlled feeding management conditions, and therefore, might not be representative of commercial beef herds reared under various feeding and grazing management systems, especially in Japanese Black 
breeding cattle herds fed home-pasture roughage. We previously reported one Japanese Black breeding herd, in which all cows exhibited abnormal BUN concentrations (mean, 2.2 $\mathrm{mg} / \mathrm{d} l$; range, $1.6-4.0 \mathrm{mg} / \mathrm{d} l$ ), and indicated that the routine examination of metabolic profiles in breeding cattle herds, especially those fed roughage from their home pastureland, might be a useful tool for identifying subclinical metabolic failure in the herd. Additionally, we suggested that poor reproductive performance of the breeding herd is caused by inadequate nutritional content of the roughage arising from the conditions relating to a particular soil type of the pastureland [21]. BUN has been shown to be a sensitive indicator of the balance between amount and availability of digestible $\mathrm{CP}$ and energy fed to ruminants [4], and BUN helps measure efficiency of protein utilization $[6,7]$. On the other hand, some studies have reported a negative effect of high BUN on fertility in beef cattle, while others have indicated reduced conception risks when milk urea nitrogen was either very low or very high in dairy cattle $[2,12]$. Although we did not examine both roughage and soil conditions of the pastureland of each herd in this study, biochemical analyses from breeding herds in our jurisdiction may reflect regional differences of protein/energy metabolism of each cattle herd possibly due to nutritional differences of the roughage harvested from the home pasturelands. Additionally, although the herds from all 3 areas included cows with abnormally low BUN and Glu levels, approximately half of the examined herds in Area 2 included cows with abnormally low BUN $(<6 \mathrm{mg} / \mathrm{d} l)$ and Glu $(<45 \mathrm{mg} / \mathrm{d} l)$. Therefore, the present study also indicates the practical usefulness of our MPT during both the prepartal and the postpartal periods to detect herds with subclinical metabolic problems. Further epidemiological investigation for clarifying the relationship among the serum metabolic profile, nutritional content of the fed roughage, and soil quality according to the geographic area of our jurisdiction in the Osumi Peninsula in Kyushu, Japan, is warranted.

In conclusion, the results of our field investigation confirmed that the routine examination of metabolic profiles, especially BUN, of breeding cattle herds particularly fed on roughage from home pastureland, is a useful tool for determining subclinical metabolic disorders of the cattle herd with normal BCS under saturated feed volume conditions. Additionally, it was strongly suggested that the occurrence of poor/unsatisfactory reproductive performance of the beef breeding cattle herd might be due to inadequate nutritional content of the diet, possibly arising from regional differences of pastureland conditions; thus, appropriate feeding management based on objective evaluation of the dietary feeds, especially the roughage from home pastureland, may improve reproductive performance of the breeding cattle herds in our jurisdiction.

\section{REFERENCES}

1. Agriculture, Forestry and Fisheries Research Council Secretariat, MAFF ed. 2008. Japanese Feeding Standard for Beef Cattle 1st ed., Central Association of Livestock Industry, Tokyo (in Japanese).
2. Carlsson, J. and Pehrson, B. 1993. The relationships between seasonal variations in the concentration of urea in bulk milk and the production and fertility of dairy herds. Zentralbl. Veterinarmed. A 40: 205-212. [Medline]

3. Hess, B. W., Lake, S. L., Scholljegerdes, E. J., Weston, T. R., Nayigihugu, V., Molle, J. D. C. and Moss, G. E. 2005. Nutritional controls of beef cow reproduction. J. Anim. Sci. 83: E90-E106.

4. Kenny, D. A., Boland, M. P., Diskin, M. G. and Sreenan, J. M. 2002. Effects of rumen degradable protein with or without fermentable carbohydrate supplementation on blood metabolites and embryo survival in cattle. Anim. Sci. 74: 529-537.

5. Kida, K. 2002. The metabolic profile test: its practicability in assessing feeding management and periparturient diseases in high yielding commercial dairy herds. J. Vet. Med. Sci. 64: 557-563. [Medline] [CrossRef]

6. Kohn, R. A., Kalscheur, K. F. and Russek-Cohen, E. 2002. Evaluation of model to estimate urinary nitrogen and expected milk urea-nitrogen. J. Dairy Sci. 85: 227-233. [Medline] [CrossRef]

7. Manston, R., Russell, A. M., Payne, J. M. and Dew, S. M. 1975. The influence of dietary protein upon blood composition in dairy cows. Vet. Rec. 96: 497-502. [Medline] [CrossRef]

8. McSweeney, C. S., Fitzpatrick, L. A., D'Occhio, M. J., Reid, D. and Entwistle, K. W. 1993. Reducing post-partum anoestrus interval in first-calf Bos indicus crossbred beef heifers. I. Effects of pre-and post-partum supplementation strategies. Aust. J. Agric. Res. 44: 1063-1077. [CrossRef]

9. Okada, K., Takoh, M., Naito, Y. and Takeuchi, A. 1999. Relationship between occurrence of white diarrhea and changes of properties and components of blood and milk in their dams after parturition in Japanese Black calves. J. Vet. Med. Sci. 61: 929-934. [Medline] [CrossRef]

10. Oliveira Filho, B. D., Toniollo, G. H., Oliveira, A. F. D., Viu, M. A. O., Ferraz, H. T., Lopes, D. T. and Gambarini, M. L. 2010. The effect of offering an energy and protein supplement to grazing Canchim beef cows either postpartum or both pre- and postpartum on lipid blood metabolites and folliculogenesis. Anim. Reprod. Sci. 121: 39-45. [Medline] [CrossRef]

11. Payne, J. M., Dew, S. M., Manston, R. and Faulks, M. 1970. The use of a metabolic profile test in dairy herds. Vet. Rec. 87: 150-158. [Medline] [CrossRef]

12. Pehrson, B., Plym Forshell, K. and Carisson, J. 1992. The effect of additional feeding on the fertility of high-yielding dairy cows. Zentralbl. Veterinarmed. A 39: 187-192. [Medline]

13. Radostits, O. M., Gay, C. C., Blood, D. C. and Hinchcliff, K. W. 2000. Reference laboratory values. pp. 1819-1822. In: Veterinary Medicine, 9th ed., W.B. Saunders Company, London.

14. Refsdal, A. O. 2000. To treat or not treat: a proper use of hormones and antibiotics. Anim. Reprod. Sci. 60-61: 109-119. [Medline] [CrossRef]

15. Sasser, R. G., Williams, R. J., Bull, R. C., Ruder, C. A. and Falk, D. G. 1988. Postpartum reproductive performance in crude protein-restricted beef cows: return to estrus and conception. $J$. Anim. Sci. 66: 3033-3039. [Medline]

16. Short, R. E. and Adams, D. C. 1988. Nutritional and hormonal interrelationships in beef cattle reproduction. Can. J. Anim. Sci. 68: 29-39. [CrossRef]

17. Sithyphone, K., Yabe, M., Horita, H., Hayashi, K., Fumita, T., Shiotsuka, Y., Etoh, T., Ebara, F., Samadmanivong, O., Wegner, J. and Gotoh, T. 2011. Comparison of feeding systems: feed cost, palatability and environmental impact among hay-fattened beef, consistent grass-only-fed beef and conventional marbled beef in Wagyu (Japanese Black cattle). Anim. Sci. J. 82: 352-359. [Medline] [CrossRef] 
18. Stagg, K., Spicer, L. J., Sreenan, J. M., Roche, J. F. and Diskin, M. G. 1998. Effect of calf isolation on follicular wave dynamics, gonadotropin and metabolic hormone changes, and interval to first ovulation in beef cows fed either of two energy levels postpartum. Biol. Reprod. 59: 777-783. [Medline] [CrossRef]

19. Sullivan, T. M., Micke, G. C. and Perry, V. E. A. 2009. Influences of diet during gestation on potential postpartum reproduction performance and milk production of beef heifers. Theriogenology 72: 1202-1214. [Medline] [CrossRef]

20. Tabata, Y., Togo, D., Kitagawa, M., Oishi, K., Kumagai, H., Kume, S. and Hirooka, H. 2009. Nitrogen, phosphorus and po- tassium utilization and their cycling in a beef-forage production system. Anim. Sci. J. 80: 475-485. [Medline] [CrossRef]

21. Watanabe, U., Okamoto, K., Miyamoto, A., Otoi, T., Yamato, O., Tshering, C. and Takagi, M. 2012. A Japanese Black breeding herd exhibiting low blood urea nitrogen: a metabolic profile study examining the effect on reproductive performance. Anim. Sci. J. (In press).

22. Yonai, M., Geshi, M., Sakaguchi, M. and Suzuki, O. 1995. The relationship between the first estrus and the change of plasma cholesterol concentration during pre and postpartum in Japanese Black cattle. J. Reprod. Dev. 41: j1-j8. [CrossRef] 